\title{
水分量の異なる不飽和土壤の複素誘電スペクトルの評価
}

\author{
上村将彰 ${ }^{1} \cdot$ 中川 啓 ${ }^{2} \cdot$ 宮本英揮 $^{* 3}$ \\ ${ }^{1}$ 鹿児島大学大学院連合農学研究科 $890-8580$ 鹿児島県鹿児島市郡元 1-21-24 \\ ${ }^{2}$ 長崎大学総合生産科学域 852-8521 長崎県長崎市文教町 1-14 \\ ${ }^{3}$ 佐賀大学農学部 840-8502 佐賀県佐賀市本庄町本庄 1
}

\section{Estimating the Dielectric Spectrum of Unsaturated Soils with Different Moisture Contents}

\author{
Masaaki UEMURA ${ }^{1}$, Kei NAKAGAWA ${ }^{2}$ and Hideki MiYAMOTO*3 \\ ${ }^{1}$ The United Graduate School of Agricultural Sciences, Kagoshima University, 1-21-24 Korimoto, \\ Kagoshima 890-8580, Japan. \\ ${ }^{2}$ Institute of Integrated Science and Technology, Nagasaki University, 1-14 Bunkyo-machi, \\ Nagasaki 852-8521, Japan. \\ ${ }^{3}$ Faculty of Agriculture, Saga University, 1 Honjo-machi, Saga 840-8502, Japan.
}

\begin{abstract}
To establish a method for evaluating the dielectric spectra of unsaturated soils, spectra of the real permittivity of Toyoura standard sands $\left(\varepsilon_{\text {sand }}^{\prime}\right)$ with different volumetric water contents $(\theta)$ were determined by employing a vector network analyzer. Their results were verified based on a comparison with the theoretical values calculated using a modified dielectric mixing model. The spectra of $\varepsilon_{\text {sand }}^{\prime}$ above $0.23 \mathrm{~m}^{3} \mathrm{~m}^{-3}$ could not be estimated owing to unreproducible soil packing. However, suitable spectra that approximately agreed with the theoretical spectra, were successfully estimated when $\theta$ was less than $0.19 \mathrm{~m}^{3}$ $\mathrm{m}^{-3}$. Although further modifications of the foregoing approaches are required to obtain more reliable spectra of $\varepsilon_{\text {sand }}^{\prime}$ for Toyoura standard sands with high moisture contents, the proposed methods can aid in evaluating the spectra of unsaturated sands with low or moderate volumetric water contents.
\end{abstract}

Keywords: calibration, dielectric spectroscopy, dielectric spectrum, soil moisture

\begin{abstract}
諸言
作物の収量・品質の向上を図る手段の 1 つとして, 根圈 水分環境の制御が挙げられる. 水分環境の指標となる土壌 の体積含水率 $(\theta)$ は, 時間領域反射法 $(\mathrm{TDR})^{1,2)}$, 時間
\end{abstract}

2020 年 2 月 10 日受付

2020 年 6 月 7 日受理

*Corresponding author: Hideki Miyamoto (b1098@cc.saga-u.ac.jp)
領域透過法 $(\mathrm{TDT})^{3,4)}$, 静電容量法 ${ }^{5,6}$ 等の電気的性質に 基づき間接的に測定でき, その簡易測定を支援するための 多様な水分センサーが流通している.

水分センサーを利用して, $\theta$ を正確に測定することは容易 ではない ${ }^{7)}$. センサー感知部周囲の土壤の電気的性質, たと えば, 電磁波の伝播時間 (または伝播速度), 電気抵抗, 静 電容量等を決定し, それを所定の経験式に代入して $\theta$ に変 換するのが, 水分センサーによる一般的な $\theta$ 測定法である. しかし, その経験式は, 土壤の種類およびその乾燥密度等に よって異なるため ${ }^{8,9)}$, 別途, キャリブレーションを行わない限 り, 正確な $\theta$ を得ることが難しい. キャリブレーションを適切に 
行うには, 実験に対する高い習熟度に加え反復測定の手間 を要することから，それをせずに $\theta$ の相対的変化を測定する ユーザーが多い. 正確な $\theta$ を得ることが出来ないことから, $\theta$ 值や水分特性曲線を介して得られる $\mathrm{pF}$ 等を指標とした精密 な水分環境制御を実現できていないのが現状である. 簡便で 正確な水分センサーのキャリブレーション法を確立することは, データの価值の向上と精密な根圈水分環境制御の実現に資 すると考えられる ${ }^{7}$.

簡便なキャリブレーション法として, 流体を供試材料とした 簡易法が検討されている ${ }^{10)}$.この手法は, 電気的性質の異 なる複数の流体の複素誘電率の実数部 $\left(\varepsilon^{\prime}\right)$ と, 同一流体 に対する水分センサーの出力值との経験的関係を実験的に 定めた後, それをTopp 式 $\left.{ }^{11}\right)$ に代表される既存の経験式 $\left(\varepsilon^{\prime}\right.$ $-\theta)$ にあてはめるものである ${ }^{12,13)} . \varepsilon^{\prime}$ を介したセンサー出力值 の $\theta$ への変換の最大の利点は, センサー感知部との完全接 触が期待でき, 且つ均一な流体を供試材料とするため, デー 夕のばらつきが小さく, 測定の再現性が高いことにある. ただ し, この手法を適用できるのは, 使用するセンサーの周波数 $(f)$ において, $\varepsilon^{\prime}$ と $\theta$ との経験的関倸が既知である場合に限 られる. 換言すれば, 各周波数における $\varepsilon^{\prime}-\theta$ の関係が既知 であれば, 流体を利用した簡易校正を実施できることを意味 する. ところが, 任意の周波数における測定事例は, 液体や 粘土に代表される流動性の高いペースト状の試料に限ら $れ^{14,15)}$, 間隙中に空気を含む水分不飽和土壤に対する事例 は認められない。

本研究では, 水分不飽和土壌の実数部スペクトルの態様 を明らかにするために, 2 つ異なる手法を検討した. 第 1 に, ベクトルネットワークアナライザー (VNA) を利用して, $\theta$ の 異なる豊浦砂の複素誘電率の実数部 $\left(\varepsilon_{\text {sand }}^{\prime}\right)$ スペクトルを反 復測定した. 第 2 に, 誘電率に関する既往のモデルを改良す ることによって $\varepsilon_{\text {sand }}^{\prime}$ の評価モデルを構築し，それに基づき $\varepsilon_{\text {sand }}^{\prime}$ スペクトルを計算した. VNAによる測定結果と改良モデルに 基づく計算值を比較し, 水分不飽和状態の豊浦砂の $\varepsilon_{\text {sand }}^{\prime}$ ス ペクルルの全体像を把握するとともに, 両手法の課題を明らか にすることを試みた。

\section{材料および方法}

\section{1. 豊浦砂の複素誘電スペクトル測定}

$25{ }^{\circ} \mathrm{C}\left( \pm 0.5{ }^{\circ} \mathrm{C}\right)$ の実験室内に, VNA（N5230A, Agilent Technologies) と誘電体プローブキット $(85070 \mathrm{E}$, Agilent Technologies）とを組み合わせた複素誘電スペク卜 ル測定システムを構築した. 同軸ケーブルおよび電子校正用 Ecal モジュールを介して, $500 \mathrm{MHz} \sim 50.0 \mathrm{GHz}$ の周波数に 対応した直径 $2.2 \mathrm{~mm}$, 長さ $200 \mathrm{~mm}$ のスリムフォームプローブ

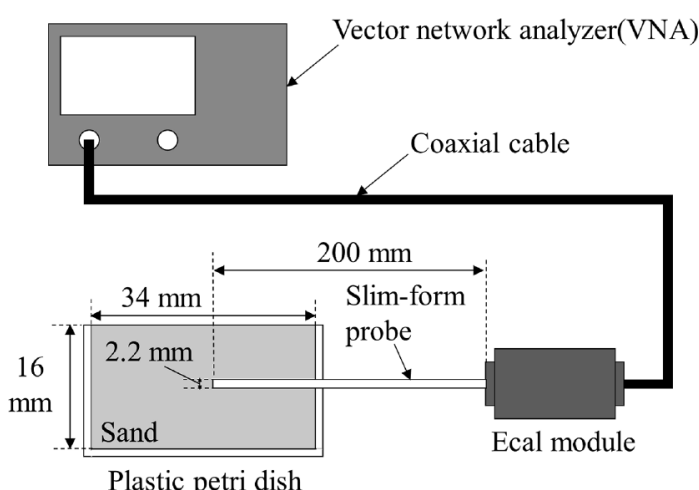

Plastic petri dish

Fig. 1 Schematic diagram of experiments.

（Agilent Technologies）をVNAに接続し，それを水平に固 定した状態で, 誘電体プローブキット付属ソフトウェアを用いて 測定システム全体のキャリブレーションを行った（Fig. 1). 我 が国の標準砂として知られる豊浦砂と蒸留水とをビニル袋内 で混合し, 両者の混合比を調整することによって, $\theta$ の異なる 計 10 種の供試土壤を準備した. そして, プラスチック製シャ ーレ（内径: $34 \mathrm{~mm}$, 高さ: $16 \mathrm{~mm}$ ) の側面の中間高さに設 けた小孔からスリムフォームプローブを水平に插入した後, 所 定の $\theta$ の供試土壤をシャーレ内に充填して転圧したうえで, 供試土壤表面における水分の蒸発を防ぐために上面を密閉 した (Fig. 1).

上述の測定システムを利用して, $\theta$ を調整した供試土壌の ๕'スペクトルを測定した. スリムフォームプローブの測定下限 周波数が $500 \mathrm{MHz}$ であること, また土壤水分測定に多用さ れる周波数が数百 $\mathrm{MHz} \sim 1 \mathrm{GHz}$ 超であること等を考慮し て, 本研究では, それを網羅する $500 \mathrm{MHz} \sim 4.0 \mathrm{GHz}$ の周 波数带を $\varepsilon_{\text {sand }}^{\prime}$ スペクトルの測定対象周波数と定めた. そし て, 測定システムの最大分解能が発揮されるよう, その周波 数帯域を最大分割数で等分した計 511 の分割点の $\varepsilon_{\mathrm{sand}}^{\prime}$ 值 を測定し,これらを 1 組の $\varepsilon_{\text {sand }}^{\prime}$ スペクトルとした. 測定終了 後, 供試土畩をシャーレから取り出して, 炉乾法 $\left(105^{\circ} \mathrm{C}\right)$ によ り $\theta$ を決定した. 同一手順で試料の充填, $\varepsilon_{\text {sand }}^{\prime}$ スペクトル測 定, $\theta$ 測定等を計 50 反復し, $\varepsilon_{\text {sand }}^{\prime}$ の平均スペクトルおよび $\theta$ の平均值を求めた.

以上の測定を, 全 $\theta$ 条件において反復した. なお, 全実験 条件に扔ける供試土壌の間隙率 $(\phi)$ 抢よび乾燥密度の平 均值は, それぞれ $0.42 \mathrm{~m}^{3} \mathrm{~m}^{-3}$ および $1.50 \mathrm{~g} \mathrm{~cm}^{-3}$ であった. また, 各供試土壌の $\theta$ の平均值は, それぞれ $0.001,0.05$, $0.09,0.14,0.19,0.23,0.24,0.27,0.29,0.32 \mathrm{~m}^{3} \mathrm{~m}^{-3}$ であつ た.

2. 自由水の誘電分散を考慮した改良型誘電率混合モデル 土壤の誘電率を表す代表的なモデルの1つに, 
Maxwell-DeLoor モデル ${ }^{16)}$ がある. 土壌は, 土粒子, 自由 水, 吸着水, 空気の計 4 成分から構成され, 且つ各構成成 分の存在比を重みとして与えた先行研究 ${ }^{16)}$ によれば, このモ デルに基づき $\varepsilon_{\text {sand }}^{\prime}$ を次式で表すことができる.

$\varepsilon_{\text {sand }}^{\prime}=$

$$
\frac{3 \varepsilon_{\mathrm{s}}^{\prime}+2\left(\theta-\theta_{\mathrm{bw}}\right)\left(\varepsilon_{\mathrm{fw}}^{\prime}-\varepsilon_{\mathrm{s}}^{\prime}\right)+2 \theta_{\mathrm{bw}}\left(\varepsilon_{\mathrm{bw}}^{\prime}-\varepsilon_{\mathrm{s}}^{\prime}\right)+2(\phi-\theta)\left(\varepsilon_{\mathrm{a}}^{\prime}-\varepsilon_{\mathrm{s}}^{\prime}\right)}{3+\left(\theta-\theta_{\mathrm{bw}}\right)\left(\frac{\varepsilon_{\mathrm{s}}^{\prime}}{\varepsilon_{\mathrm{fw}}^{\prime}}-1\right)+\theta_{\mathrm{bw}}\left(\frac{\varepsilon_{\mathrm{s}}^{\prime}}{\varepsilon_{\mathrm{bw}}^{\prime}}-1\right)+(\phi-\theta)\left(\frac{\varepsilon_{\mathrm{s}}^{\prime}}{\varepsilon_{\mathrm{a}}^{\prime}}-1\right)}
$$

$\theta_{\mathrm{bw}}$ は吸着水の体積分率 $\left(\mathrm{m}^{3} \mathrm{~m}^{-3}\right), \phi$ は間隙率 $\left(\mathrm{m}^{3} \mathrm{~m}^{-3}\right)$

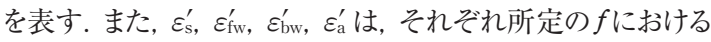
土粒子, 自由水, 吸着水, 空気の実数部を表す.ただ, 土 粒子表面の吸着水の誘電率は強い周波数依存性を示すこと が知られているものの, その挙動や周波数特性については未 解明な点が多い ${ }^{17)}$. 吸着水は, 土粒子表面に強く吸着され て存在するため, 一般に, 比表面積が大きい土㙵ほど, 全水 分に占める吸着水の割合は大きい. しかし, 粒径が比較的大 きい土粒子を主成分とする砂の場合，粘土分を多量に含む 土壤に比べ比表面積は非常に小さいことから, 本研究では, 豊浦砂の $\theta$ に占める吸着水の割合は無視できるほど小さい,
すなわち, $\theta_{\mathrm{bw}}=0$ とみなすことにより, (1) 式を次式のように簡 略化することとした.

$$
\varepsilon_{\mathrm{sand}}^{\prime}=\frac{3 \varepsilon_{\mathrm{s}}^{\prime}+2 \theta\left(\varepsilon_{\mathrm{fw}}^{\prime}-\varepsilon_{\mathrm{s}}^{\prime}\right)+2(\phi-\theta)\left(\varepsilon_{\mathrm{a}}^{\prime}-\varepsilon_{\mathrm{s}}^{\prime}\right)}{3+\theta\left(\frac{\varepsilon_{\mathrm{s}}^{\prime}}{\varepsilon_{\mathrm{fw}}^{\prime}}-1\right)+(\phi-\theta)\left(\frac{\varepsilon_{\mathrm{s}}^{\prime}}{\varepsilon_{\mathrm{a}}^{\prime}}-1\right)}
$$

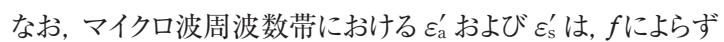
概ね一定值を示す ${ }^{18)}$ ため, $\varepsilon_{\mathrm{a}}^{\prime}$ は $1.0, \varepsilon_{\mathrm{s}}^{\prime}$ は 2.6 であるとする と, (2) 式は

$$
\varepsilon_{\mathrm{sand}}^{\prime}=\frac{7.8+2 \theta\left(\varepsilon_{\mathrm{fw}}^{\prime}-2.6\right)-3.2(\phi-\theta)}{3+\theta\left(\frac{2.6}{\varepsilon_{\mathrm{fw}}^{\prime}}-1\right)+1.6(\phi-\theta)}
$$

となる.

一方, $\varepsilon^{\prime}$ が $f$ よって異なる, すなわち, 誘電分散を示す 流体 $^{15)}$ の $\varepsilon^{\prime}$ は, 次の Debye モデルにより表される ${ }^{19)}$.

$$
\varepsilon^{\prime}=\varepsilon_{\infty}^{\prime}+\frac{\varepsilon_{0}^{\prime}-\varepsilon_{\infty}^{\prime}}{1+\omega^{2} \tau^{2}}
$$

$\omega$ は角周波数 $(=2 \pi f)$, $\varepsilon_{\infty}^{\prime}$ は極限の周波数における実数 部, $\varepsilon_{0}^{\prime}$ は最低周波数における実数部, $\tau$ は緩和時間をそれ ぞれ表す. $\varepsilon_{\infty}^{\prime}, \varepsilon_{0}^{\prime}, \tau$ の者は温度の関数として表され, 25 ${ }^{\circ} \mathrm{C}$ 水の場合は, それぞれ $5.3,78.3,8.7 \times 10^{-12} \mathrm{~s}$ であ
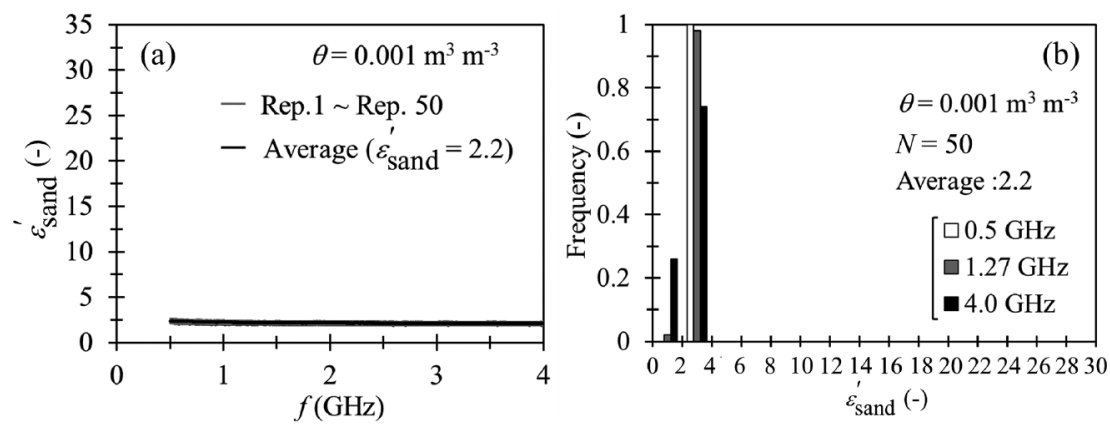

Fig. 2 (a)Spectra of real permittivity ( $\left.\varepsilon_{\text {sand }}^{\prime}\right)$ of Toyoura sand for $\theta=0.001 \mathrm{~m}^{3} \mathrm{~m}^{-3}$ and (b) their histogram plot for $0.5,1.27$, and $4.0 \mathrm{GHz}$.
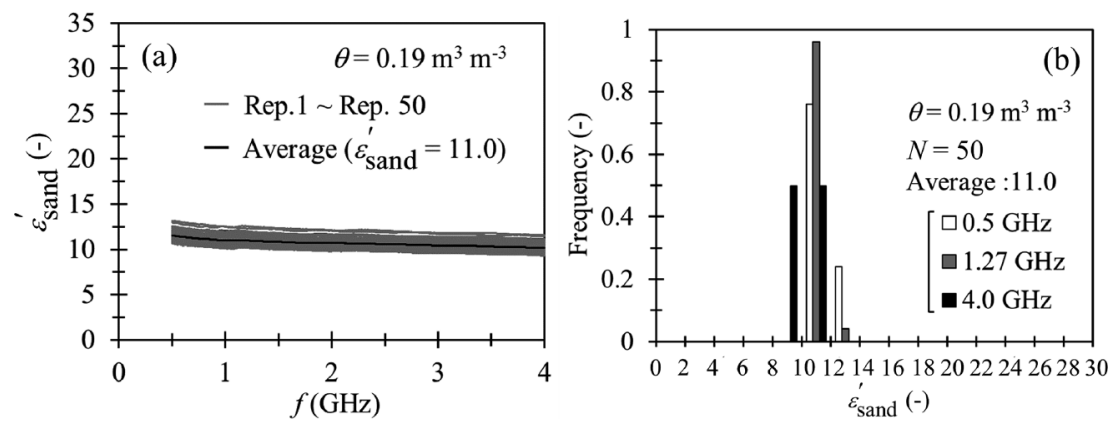

Fig. 3 (a)Spectra of real permittivity ( $\varepsilon_{\text {sand }}^{\prime}$ ) of Toyoura sand for $\theta=0.19 \mathrm{~m}^{3} \mathrm{~m}^{-3}$ and (b) their histogram plot for $0.5,1.27$, and $4.0 \mathrm{GHz}$. 
る ${ }^{19)}$. 上述のように, $\theta_{\mathrm{bw}}$ を無視することは, 間隙内が自由水 で満たされることと同義である. よって, 自由水の $\varepsilon^{\prime} を \varepsilon_{\mathrm{fw}}^{\prime}$ と置 き換えたうえで, 3 つの定数を (4) 式に代入すると,

$$
\varepsilon^{\prime}=\varepsilon_{\mathrm{fw}}^{\prime}=5.3+\frac{73}{1+(2 \pi f)^{2}\left(8.7 \times 10^{-12}\right)^{2}}
$$

となり, 所定の $f$ に打ける自由水の $\varepsilon_{\mathrm{fw}}^{\prime}$ を算出可能である. (5) 式に基づいて算出した $\varepsilon_{\mathrm{fw}}^{\prime}$ を(3) 式に代入することにより,

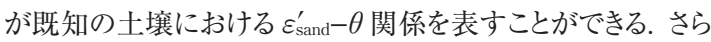
に, (3) 式に (5) 式を代入して $\varepsilon_{\mathrm{fw}}^{\prime}$ を消去すれば, $f, \theta, \varepsilon_{\text {sand }}^{\prime}$ の三者の関係を定式化できる.

\section{結果と考察}

\section{1. 豊浦砂の複素誘電スペクトル}

最も $\theta$ が小さい $0.001 \mathrm{~m}^{3} \mathrm{~m}^{-3}$ では, 乾燥した豊浦砂の特 徵を反映した $\varepsilon_{\text {sand }}^{\prime}$ スペクトルが得られた（Fig. 2(a)). 計 50 回の測定によって得られた $\varepsilon_{\text {sand }}^{\prime}$ スペクトルは $1.8 \sim 2.7$ の範 囲に分布し, $f$ にる $\varepsilon_{\text {sand }}^{\prime}$ の差異は小さかった（Fig. 2(a)）. 本測定システムの測定周波数の下限 $(0.5 \mathrm{GHz})$ および上限 (4.0 GHz) に加え，マイクロ波リモートセンシングに適用され る土壤水分感応帯 $(1.27 \mathrm{GHz})^{20)}$ に着目した. これら 3 つの

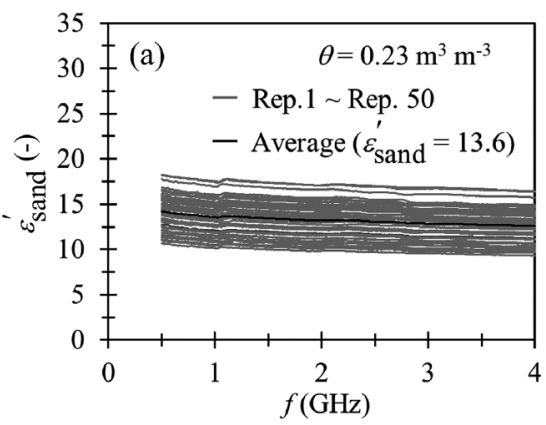

周波数における $\varepsilon_{\text {sand }}^{\prime}(0 \sim 30)$ を 15 分割し, 各 bin 幅を 2 と したヒストグラムを図示した結果, 計 50 回の平均值（2.2）の 近傍において, 各周波数の頻度が突出した (Fig. 2(b)). 土 壤構成成分のうち, 最も高い $\varepsilon^{\prime}$ を示す水の割合が最も小さ く, 逆に低 $\varepsilon^{\prime}$ 值を示す土粒子 $\left(\varepsilon_{\mathrm{s}}^{\prime}=2.6\right)$ 抢よび空気 $\left(\varepsilon_{\mathrm{a}}^{\prime}=\right.$ 1.0）の割合が高いこと, そして両者が誘電分散を示さない 誘電体であること等が, $\varepsilon_{\text {sand }}^{\prime}$ 值の低さおよびその低周波数依 存性の原因であると考える.

高 $\theta$ の条件ほど, 反復測定した $\varepsilon_{\text {sand }}^{\prime}$ スペクトルの值とその ばらつきが大きくなった. $\theta=0.001 \mathrm{~m}^{3} \mathrm{~m}^{-3}$ の場合（Fig. 2(a) および (b)) と比較すると, $\theta=0.19 \mathrm{~m}^{3} \mathrm{~m}^{-3}$ の $\varepsilon_{\text {sand }}^{\prime}$ はより大き な $9.3 \sim 13.2$ の範囲に分布し (Fig. 3(a)), 平均值 (11.0) に対するヒストグラムの水平への広がりが顕著となった（Fig. 3(b)). さらに $\theta$ が高い 0.23 执よ゙ $0.32 \mathrm{~m}^{3} \mathrm{~m}^{-3}$ では, $\theta$ が高 いほど $\varepsilon_{\text {sand }}^{\prime}$ 值は大きくなったのに対して, ヒストグラムはさらに 水平に広がる分布を示した (Fig. 4(b), Fig. 5(b)). $\theta$ の増 加に対する $\varepsilon_{\text {sand }}^{\prime}$ スペクトルおよびヒストグラムの変化傾向は, 全 $\theta$ 条件に共通する現象であった（図は割愛).

本測定システムによる測定の再現性が急変する $\theta$ 条件が 認められた. 0.5, $1.27,4.0 \mathrm{GHz}$ におけるヒストグラムが, 高 $\theta$ の条件ほど水平方向へ広がったように（Fig. 2～5), これら

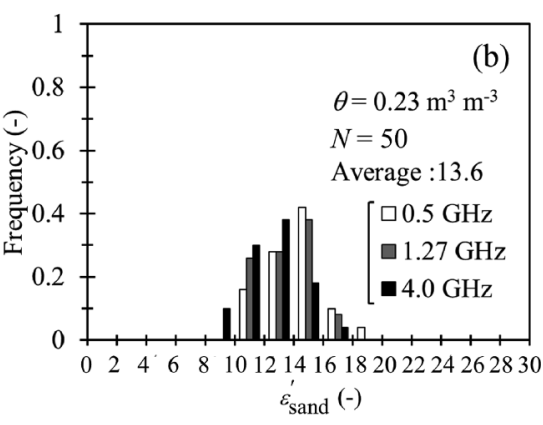

Fig. 4 (a)Spectra of real permittivity ( $\left.\varepsilon_{\text {sand }}^{\prime}\right)$ of Toyoura sand for $\theta=0.23 \mathrm{~m}^{3} \mathrm{~m}^{-3}$ and (b) their histogram plot for $0.5,1.27$, and $4.0 \mathrm{GHz}$.
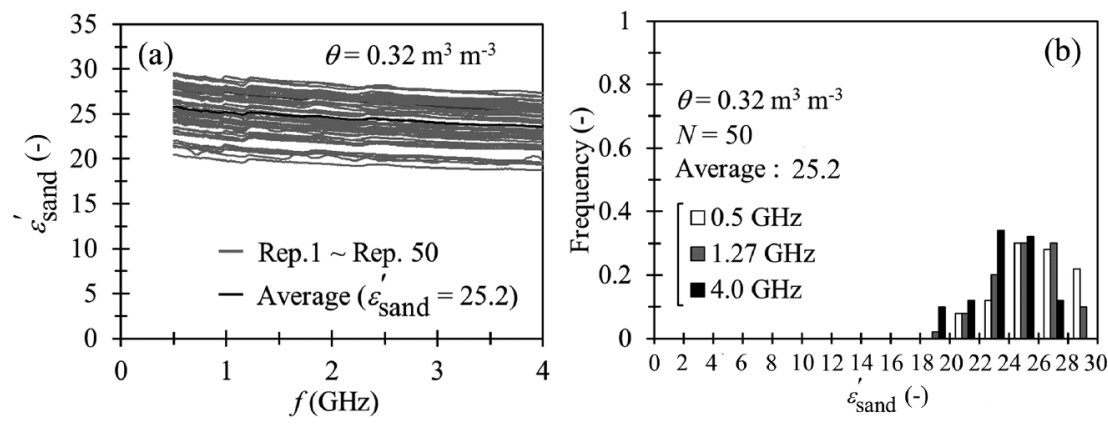

Fig. 5 (a)Spectra of real permittivity ( $\left.\varepsilon_{\text {sand }}^{\prime}\right)$ of Toyoura sand for $\theta=0.32 \mathrm{~m}^{3} \mathrm{~m}^{-3}$ and (b) their histogram plot for $0.5,1.27$, and $4.0 \mathrm{GHz}$. 
の周波数における $\varepsilon_{\text {sand }}^{\prime}$ の標準偏差も, $\theta$ とともに大きくなった (Fig. 6).ただし, $\theta \leq 0.19 \mathrm{~m}^{3} \mathrm{~m}^{-3}$ では, 各周波数における 標準偏差が, $\theta$ に対してほぼ直線的に変化したのに対して, $\theta \geq 0.23 \mathrm{~m}^{3} \mathrm{~m}^{-3}$ では急増する 3 つの条件 $(\theta=0.23,0.29$, $0.32 \mathrm{~m}^{3} \mathrm{~m}^{-3}$ ) が認められた (Fig. 6). 土壤の誘電率を測定 する際, センサー感知部と豊浦砂との接触, 換言すれば, プ ローブの影響領域内の土粒子 - 水 - 空気の配列が, $\varepsilon_{\text {sand }}^{\prime}$ に大き〈影響し得る ${ }^{21,22)}$. 土の締め固めに関する既往の土質 工学研究 ${ }^{23)}$ によれば, 豊浦砂が最も密に充填される $\theta$ は $0.21 \mathrm{~m}^{3} \mathrm{~m}^{-3}$ である. この $\theta$ は, 標準偏差が急増する領域に 存在したことが興味深い. $\theta$ がそれを超えると, 間隙内部の自 由水が, 土粒子の密な充填を阻む要因となるため, 転圧によ る外力の作用によって土粒子 - 水 - 空気の配列は変わりや すかったことが, 標準偏差の急増の原因であろう. 高 $\theta$ 条件 の土壤の充填・締固めの難しさは, 粗大粒子を多く含む土壤 ほど難しいことは広く知られる事実であるものの, このような性 質を示す土壤の $\varepsilon_{\text {sand }}^{\prime}$ スペクルルの測定精度を向上させるため には, 加圧・減圧用チャンバーに豊浦砂を充填し, 加圧また は吸引圧を与えて $\theta$ を制御する水分調整法 ${ }^{4)}$ を採用するこ とが望ましいと考える. ただし，本測定システムは極めて繊細 な電子機器から構成されるため, 使用条件においてキャリブ レーションを定期的に行う必要がある. チャンバー内にプロー ブを固定するとそれを行うことが困難となる. $\varepsilon_{\text {sand }}^{\prime}$ の精度向上 を図るためには, 不飽和土壤に適したチャンバー一体型セン サーおよびそのキャリブレーション法を一体的に開発すること が必要となろう.

豊浦砂の $\varepsilon_{\text {sand }}^{\prime}$ スペクルルは, $\theta$ に応じた $f$ への依存性を示 した（Fig. 7). 先述のように, 各 $\theta$ の $\varepsilon_{\text {sand }}^{\prime}$ スペクトルのばらつ きが認められたため, 各供試土壤の計 50 回の $\varepsilon_{\text {sand }}^{\prime}$ スペク卜 ルの平均值（以後, 平均スペクトルと称す）を同一眓中に図 示した結果, 土壤水分感能帯である $1.27 \mathrm{GHz}$ 以下の周波 数存性が強くなること等が判明した. Fig. 7 に併記した水 $(\theta$ $=1.00 \mathrm{~m}^{3} \mathrm{~m}^{-3}$ ) のスペクトルが周波数依存性を示すことか ら, 水の存在比が大きい高 $\theta$ の条件ほど, $f$ への依存性が大 きかったと考える. 高 $\theta$ の条件に打いては, 今後のスペクトル 測定手法の改良を要すものの, $\theta \leq 0.19 \mathrm{~m}^{3} \mathrm{~m}^{-3}$ の $\varepsilon_{\text {sand }}^{\prime}$ の平 均スペクトル（Fig. 7）が高水分条件ほど急峻な勾配を示し た事実は, 後述する改良型誘電率混合モデルに関する本研 究の考察を支持する根拠となる実測データである.

\section{2. 改良型誘電率混合モデルによるスペクトルの推定}

改良型誘電率混合モデルに基づく $\varepsilon_{\text {sand }}^{\prime}$ スペクルルは, 先述 の本測定システム（Fig. 1）による測定結果（Fig. 7) と同 様に, $\theta$ および $f$ の依存性を示した（Fig. 8). TDRに関す る Topp $~^{11)}$ の研究や, 誘電率混合モデルを適用した過去

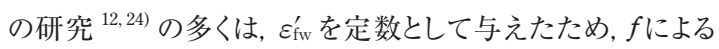

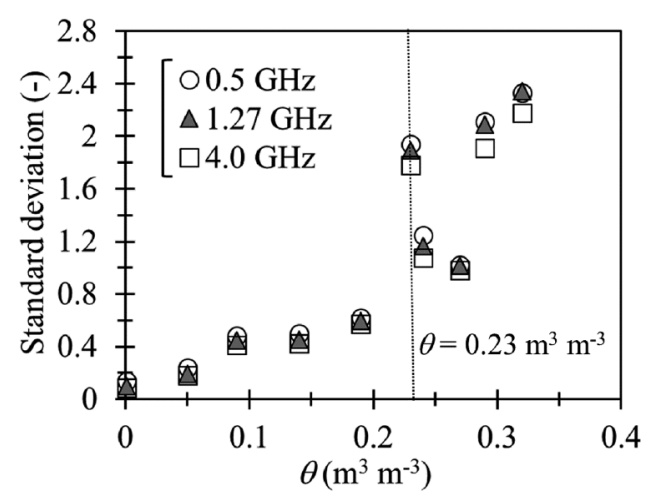

Fig. 6 Standard deviation of real permittivity at $0.5,1.27$, and $4.0 \mathrm{GHz}$ for volumetric water content $(\theta)$.

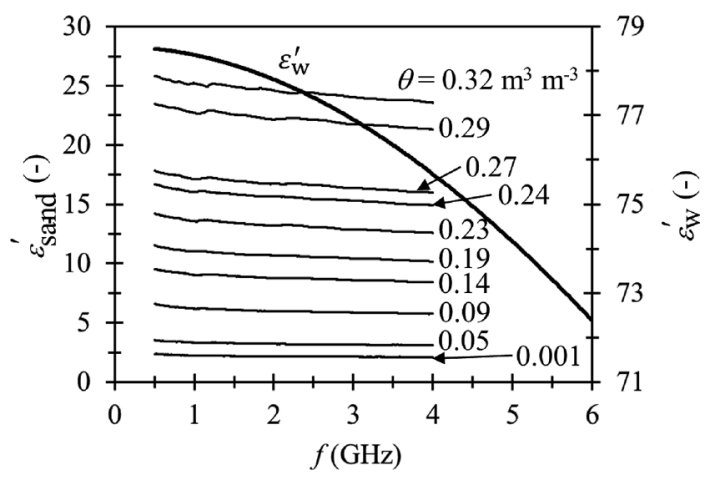

Fig. 7 Spectra of real permittivity ( $\left.\varepsilon_{\text {sand }}^{\prime}\right)$ for Toyoura sand with different volumetric water contents.

$\varepsilon^{\prime}$ の変化を表現することができなかった. しかし, 本研究の改 良型誘電率混合モデルでは, (5) 式によって水の $\varepsilon_{\mathrm{fw}}^{\prime}$ の $f$ 依 存性を考慮したため, 計算された $\varepsilon_{\text {sand }}^{\prime}$ スペクトル（Fig. 8の 破線）はfの増大とともに低下し, その低下の度合いは高 $\theta$ の条件ほど大きくなった。

$\theta \leq 0.19 \mathrm{~m}^{3} \mathrm{~m}^{-3}$ では, 改良型誘電率混合モデルに基づく $\varepsilon_{\text {sand }}^{\prime}$ スペクトル（Fig. 8の破線）は, 測定されたそれ（Fig. 8 の実線) を一定程度再現できた. ばらつきが大きかった $\theta \geq$ $0.23 \mathrm{~m}^{3} \mathrm{~m}^{-3}$ の $\varepsilon_{\text {sand }}^{\prime}$ スペクトル（Fig. 7）の測定法について は, 今後の改善が必要であるものの, $\theta \leq 0.19 \mathrm{~m}^{3} \mathrm{~m}^{-3}$ の条件 に限定すれば, モデルによる計算結果（Fig. 8の破線）と各 水分条件に扔ける実測值（Fig. 8 の実線）のスペクルルは同 一水準の領域に分布し, 両者は比較的よく一致したと考え る.ただし，計算された $\varepsilon_{\text {sand }}^{\prime}$ スペクトルのfに対する勾配は, 実測值のそれに比べ小さい. 本研究の改良型誘電率混合モ デルでは, $f に$ 対する水の誘電分散の効果を考慮したもの の, 実測值と計算值とのずれが認められた事実は, 本モデル 


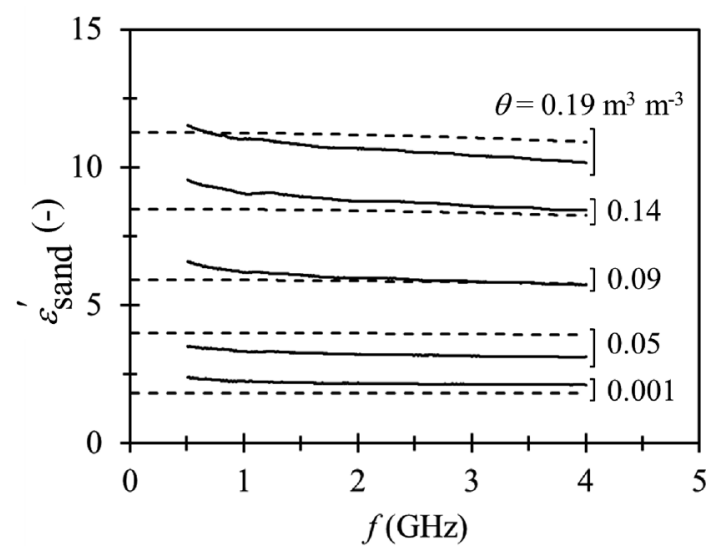

Fig. 8 Measured spectra of real permittivity of Toyoura sand (solid line) and estimated spectra by modified model (broken line).

では完全に $\varepsilon_{\text {sand }}^{\prime}$ スペクトルを表現できないことを示唆している.

コロイド化学の分野では, 比表面積が大きい粘土に発現す る特異な誘電分散 ${ }^{14,15)}$, 特に, Maxwell-Wagner 効果や表 面分極効果等に関する報告 ${ }^{17,25)}$ が認められる. 粘土に比べ 豊浦砂の比表面積が小さいことから, 本研究では吸着水の 量や上述の効果を無視できると仮定して改良型誘電率混合 モデルを, 誘導したものである. ゆえに, それらの効果を考慮 すれば $\varepsilon_{\text {sand }}^{\prime}$ スペクトルの再現性向上に繋がる可能性はあるも のの, 土粒子 - 水の界面における吸着水の挙動については 十分に解明されていないため, 誘電分散現象に関する更な る研究の進展が待たれるところである.

\section{摘 要}

本研究では, 体積含水率 $(\theta)$ の異なる豊浦砂の $\varepsilon_{\text {sand }}^{\prime}$ ス ペクトルの態様を明らかにするために, 2 つの異なる手法, す なわち, ベクトルネットワークアナライザー（VNA）を利用した 反復測定と, 既往のモデルの改良・統合によって誘導した改 良型誘電率混合モデルに基づく計算によって, $\theta$ の異なる豊 浦砂の $\varepsilon_{\text {sand }}^{\prime}$ スペクトルを評価するとともに, 両法による評価結 果を比較した.

測定した $\varepsilon_{\text {sand }}^{\prime}$ スペクトルは, 高 $\theta$ 条件ほど大きくなったもの の, そのばらつきも大きくなった. 特に, 最密充填条件 $(0.21$ $\left.\mathrm{m}^{3} \mathrm{~m}^{-3}\right)$ を越える $\theta \geq 0.23 \mathrm{~m}^{3} \mathrm{~m}^{-3}$ では, 供試土壤の転圧に 伴う土粒子 - 水 - 空気の配列の変化に起因する測定の再 現性低下により, スペクトルのばらつきが拡大した（Fig. 6). $\varepsilon_{\text {sand }}^{\prime}$ スペクトルのばらつきが比較的小さかった $\theta \leq 0.19 \mathrm{~m}^{3}$ $\mathrm{m}^{-3}$ では, 高 $\theta$ の条件ほど $\varepsilon_{\text {sand }}^{\prime}$ スペクトルは大きく, 周波数 $(f)$ への依存性も強〈なることが明らかになった.
一方, 改良型誘電率混合モデルに基づく $\varepsilon_{\text {sand }}^{\prime}$ スペクトルの 計算值は, $\theta \leq 0.19 \mathrm{~m}^{3} \mathrm{~m}^{-3}$ に限り, 測定した $\varepsilon_{\text {sand }}^{\prime}$ の平均スペ クトルと同一水準の分布となった (Fig. 8). この測定值と計 算值の共通性は, 両法によって得られたスペクトルの信頼性 を相互に担保するものと考える. しかし, モデルに基づくスペク トルは, $f に$ 対する平均スペクトルの勾配を再現することができ なかったことから, モデル誘導時に無視した吸着水の存在を 考慮する必要性が示唆された. 土粒子表面の吸着水の挙動 については不明な点が多いため, コロイド化学分野の研究の 進展を待った後, 改めて改良型誘電率混合モデルの改良に 組み込むことが必要となろう.

以上のように, 高 $\theta$ 条件における $\varepsilon_{\text {sand }}^{\prime}$ スペクトル測定手法 や, 吸着水の存在を考慮したモデルの構築等の課題が残る ものの, 本研究を通して, これまでに測定事例のない不飽和 水分土壤の $\varepsilon_{\text {sand }}^{\prime}$ スペクトルの態様の一端を明らかにした意義 は大きい. 今後は, $\varepsilon_{\text {sand }}^{\prime}$ スペクトルの測定手法およびモデルの 改良に取り組み, より精度の高い水分不飽和土壌の $\varepsilon_{\text {sand }}^{\prime}$ ス ペクトルの評価手法の確立を目指す予定である.

\section{引用文献}

1) Noborio K. Measurement of soil water content and electrical conductivity by time domain reflectometry. Computers and Electronics in Agriculture. 31: 213237. 2001.

2) Robinson DA, Jones SB, Wraith JM, Or D, Friedman SP. A review of advances in dielectric and electrical conductivity measurement in soils using time domain reflectometry. Vadose Zone Journal. 2: 444-475. 2003.

3) Harlow RC, Burke EJ, Ferré TPA. Measuring water content in saline sands using impulse time domain transmission techniques. Vadose Zone Journal. 2: 433-439. 2003.

4) 宮本英揮, 伊藤直樹, 間瀬 淳, 徳本家康, 筑紫二郎. 土壤水分・電気伝導度の同時計測への時間領域透過 法の適用. 農業農村工学会論文集. 81(6): 513-519. 2013.

5) Robinson DA, Gardner CMK, Cooper JD. Measurement of relative permittivity in sandy soils using TDR, capacitance and theta probes: comparison, including the effects of bulk soil electrical conductivity. Journal of Hydrology. 223: 198-211. 1999.

6) Dean TJ, Bell JP, Baty AJB. Soil moisture measurement by an improved capacitance technique, part I. Sensor design and performance. Journal of Hydrology. 93: 67-78. 1987.

7) 宮本英揮. 第 57 回土㙵物理学会シンポジウム総合討 論 土壌水分センサー技術情報の共有へ向けて. 土壤 
の物理性. 132: 41-44. 2016.

8) 井本博美, 西村 拓, 宮崎 毅. EC-5 センサーのキャ リブレーションとその適用. 土壌の物理性. 114: 27-31. 2010.

9) 三石正一, 溝口 勝. 静電容量型 $\mathrm{ECH}_{2} \mathrm{O}$ 土壤水分七 ンサーのキャリブレーション. 土壌の物理性. 126: 63-70. 2014.

10) Blonquist Jr JM, Jones SB, Robinson DA. A time domain transmission sensor with TDR performance characteristics. Journal of Hydrology. 314: 235-245. 2005.

11) Topp GC, Davis JL, Annan AP. Electromagnetic determination of soil water content: measurements in coaxial transmission lines. Water Resources Research. 16: 574-582. 1980.

12) 宮本英揮, 筑紫二郎. 誘電混合モデルによるカラム内壁 面接着型 TDR プローブのキャリブレーション. 土壌の物 理性. 104: 5-12. 2006.

13）伊藤祐二, 筑紫二郎, 宮本英揮. TDRによる表層土堙 水分計の開発とその有効性の評価. 土壌の物理性. 111: 35-41. 2009.

14) Ishida $T$, Makino $T$, Changjun W. Dielectricrelaxation spectroscopy of kaolinite, montmorillonite, allophane, and imogolite under moist conditions. Clays and Clay Minerals. 48(1): 75-84. 2000.

15) 宮本英揮, 下町多佳志, 筑紫二郎, 安永円理子. マイ クロ波信号領域における粘土の誘電特性. 土㖶の物理 性. 110: 13-23. 2008.

16) Dobson MC, Ulaby FT, Hallikainen MT, Elrayes MA. Microwave dielectric behavior of wet soil - Part II : dielectric mixing models. IEEE Trans. Geosci. Remote Sensing. GE-23(1): 35-46. 1985.

17）石田智之. 誘電率による粒子表面の同定. 足立泰久.
岩田進午編著, 土のコロイド現象. 学会出版センター, 東京. 129-142. 2003.

18) Mätzler C. Microwave permittivity of dry sand. IEEE Transactions on Geoscience and Remote Sensing. 36(1): 317-319. 1998.

19) 天羽優子. 誘電緩和測定ガイド. 1999. (http:// www.cml-office.org/atom11archive/ftp/pub/tdr/ TDR-guide.pdf. 2020 年 1 月 31 日参照 ).

20）会田健太郎, 小池俊雄, 開發一郎. ALOS/PALSARを 用いた土畩水分推定アルゴリズムの高頻度適用研究. 土木学会論文集 B1(水工学). 70(4): I 589-I 594 . 2014.

21) Friedman SP. A saturation degree-dependent composite spheres model for describing the effective dielectric constant of unsaturated porous media. Water Resour. Res. 34(11): 2949-2961. 1998.

22) Miyamoto T, Annaka, T, Chikushi J. Extended dual composite sphere model for determining dielectric permittivity of Andisols. Soil Sci. Soc. Am. J. 69: 2329. 2005.

23）河原荘一郎, 室 達朗, 市原一也. 重錘落下による砂 質土の一次元締固め密度と衝撃応答に及ぼす重錘質 量・落下高の影響. 土木学会論文集. 652 III-51: 2133. 2000.

24) 宮本輝仁, 筑紫二郎. 土培の体積含水率 - 比誘電率 関係への混合誘電特性モデルの適用. 農業土木学会 論文集. 206: 57-62.2000.

25) Chen Y, Or D. Effects of Maxwell-Wagner polarization on soil complex dielectric permittivity under variable temperature and electrical conductivity. Water Resour. Res. 42 W06424 DOI: 10.1029/2005WR004590. 2006. 